\title{
Research on the Problems and Countermeasures of China's Service Trade in the New Era
}

\author{
Zhijun Sheng \\ School of Economics and Management, Changchun University of Science and Technology \\ Changchun 130022, China \\ Tel: 86-135-0445-7191Ｅ-mail: shengzhijun412@126.com \\ Kuo Wang \\ School of Economics and Management, Changchun University of Science and Technology \\ Changchun 130022, China \\ Tel: 86-137-5612-4969Ｅ-mail: wangkuo1234@yahoo.com.cn
}

Received: June 23, 2012

Accepted: August 8, 2012

Online Published: October 12, 2012

doi:10.5430/ijfr.v3n4p98

URL: http://dx.doi.org/10.5430/ijfr.v3n4p98

\begin{abstract}
Since the $21^{\text {st }}$ century, global trade competitions focus point has shifted from commodity trade to service trade. International trade in services shows some new trends. Although China's service trade has obtained fast development in recent years, they also have many problems. To adapt to the new trend of the development of international service trade, China should take some countermeasures to promote China's service trade has a high level of development. These countermeasures include accelerating to develop the service industry, perfecting the legal system and management system of service trade, strengthening the personnel training work and so on.
\end{abstract}

Keywords: International trade in services, New trend, Structure of trade in services

From the $21^{\text {st }}$ century, along with the development of service economy, the key of global trade competition is shifting from commodity trade to commodity trade as well as service trade developing together; the international service trade presents a series of new characters. Recognizing and controlling the new trend of the world's service trade, making useful strategies, are awfully meaningful to accelerate the development of China's service trade, as well as alter in the pattern of foreign trade growth mode.

\section{The New Trend of International Service Trade Development}

\subsection{Service Goods Can Be Easier Traded and the International Service Trade Grows Steadily}

From the beginning of the new century, as the raising of scientific and technological level especially the network information technology level, several service goods have the qualification to transfer which could not have attended in the trading process before, which makes a big progress for those service goods to be traded, (Chen Jiyong, Yu Daoxian, 2009) so that the international service trade gained a more stable development than the commodity trade.

\subsection{The Structure of the International Service Trade Is Turning into Knowledge and Technology Densification}

Before the $21^{\text {st }}$ century, international transportation, international financial service, the wholesale and retail distribution of goods, etc. Which straightly related to international goods trade is the primary coverage of international service trade. Then after that in the new century, factor-shifting international service trade tightly related to international direct investment as well as those newly raised industry of international service trades which are relatively independent of goods trade and direct investment gradually accelerate, the structure of the service trade is turning into knowledge and technology densification structure. As manufacturing industry, international transfer of service industry will undoubtedly have an important impact on the present pattern of trade in services. (Wu Rong, 2008) 


\subsection{The Protectionism of International Service Trade Has Appeared}

Even though as WTO requested, reducing the trade barrier, many countries continuously improve the freedom of service trade development. But from the 21st century, especially after the subprime crisis broke out in the US, many countries have taken some direct or indirect protection measures on service trade and reduced service outsourcing to other countries, in order to protect native service industry development for the economic recovery, resist the possible impact bringing by trade liberalization. The interest pattern of world service trade area has changed secretly.

\subsection{The International Service Trade Competition Trends to Multiplicity}

Before the 21st century, those developed countries hold all the aces in the international service trade, they once owned over $90 \%$ in the trades, they had a huge trade surplus in service trade, USA, France, England, Italy, etc. were the most important service trade exporting countries. After the 21st century, even though some developing countries like China, India develop in a fast speed in service trade area, the volume of trade increase rapidly. The developed countries still remain the leading position, the gap between them are also obvious. However, along with the rapid development in Asian Pacific economy and the BRIC represent by China, India, more and more vigorous showed, the international service trade trends to multiplicity.

\subsection{The Emerging Service Industry Emerge Prompted the Service Trade Structure Adjustment}

Service trade has developed at an astonishing pace and its scale is continually expanding, but also relates to the more and more widely department to get involved in the field.(China IRR,2012) As the high technology has been widely applied to the service industries, accounting, consulting, computer information services and other emerging service industries continue to emerge and rapid expansion. These emerging service industry promote the rise of the world service trade structure has been further adjusted.

\section{Problems and Obstacles Exist in the Development of China's Service Trade}

\subsection{Trade in Services Sector Structure Is Irrational, Regional Structure Serve as Unbalanced}

Joining the WTO, China's service industry has gradually formed a comprehensive, multi-level pattern of opening up, but the structure of service trade sector is still not reasonable, the development of Chinese service trade structure of regional serve as unbalanced. See from the sector structure, China's services trade is mainly concentrated in traditional industries such as tourism, transportation, construction; but other technology-intensive and knowledge-intensive industry such as departments, finance, insurance, communications and consulting is still lagging behind. See from the structure of the region, developed coastal regions have a more advanced modern service industry, in the transportation insurance, computer and information services, advisory services and other fields these regions have obvious advantages. While in the developing central and western regions labor services, tourism and other traditional industries occupy a larger proportion.

\subsection{Limited Lagging Development of Service Industry, Service Trade Competitiveness Still at a Disadvantage}

Service industry is the foundation of the development of service trade. The current service industry overall level seriously affected the development of service trade. And in the open degree, China's service industry is far behind manufacturing industry, many service industries still exists different degrees of restrictions on market access. In the form of services trade, although China's service industry in the cross-border supply, consumption abroad and the presence of natural person have been became open up-and-up, permitting qualification and forms of market access have many restrictions. Under strong protection, China's relevant enterprise still has not really participated in the competition and gained a firm foothold in the world service trade market. Since the new century, China's service trade comparative advantage has not been improved obviously; China's service trade competitiveness in general is still at a disadvantage.

\subsection{Inadequate Legal System and Imperfect Management System of Trade in Services}

First, China's service trade legislation is seriously lagging behind. Since joining the WTO China has promulgated a series of laws and regulations, but has a larger gap with the requirements of the WTO rules and international practice. Secondly, due to international trade in services involved in the industry a wide range, one country has no choice to coordinate and manage the domestic service industry comprehensively. At present, there are many defects in the management system of international trade in services, such as Management of the Ministry of Commerce of longs, scattered strength, central and local differences in the service of international trade policy and regulations, vague relevant functional departments of the service sector responsibilities. These factors seriously block China to adapt the new trend of international service trade and to obtain further development way. 


\subsection{Relatively Low Quality of Personnel}

Compared with the merchandise trade, in the service trade field the subject matter of exchange serve as service, it cannot be stored, service consumption complete in the production, service providers and users have some forms of contact, which put forward higher requirements for the quality of the staff. (Wu hansong, 2008)At present, talent in services qualification is lacking, which is a prominent obstacle to improve China's international services market competitive. China's investment in education and technology in the service industry personnel is also relatively low, the cultivation of talent on the international trade in services is inadequate attention, and will directly affect the competitiveness of China's service trade in the international market.

\section{Countermeasures of Promoting the Development of China's Service Trade}

\subsection{Strengthen the Industrial Base of the Development of Service Trade}

We must vigorously develop the productive services and realize the positive interaction of the productive services and manufacturing. (The State Council, 2007)At present, China is in the process of industrialization. On the one hand, changing China from a big manufacturing country to a powerful manufacturing county depends on the rapid development of service industry. On the other hand, the positive interaction of the services and manufacturing also helps to promote China's industrial structure's optimization and upgrading, to promote the coordinated development of China's industry ,and ultimately to promote the comprehensive and rapid development of China's service trade.

\subsection{Attach Importance to Maintain and Create Service Mark and Strengthen to Copy Business Model Innovatively}

China has some little famous manufacturing brands in the international market, but it has been the lack of influential service industry brands, so it is important to conduct a definite and clear services brand strategy, and create new services brands. At the same time, we should to learn from developed countries, to dig inherent replication of business model of our own brands, to implement "going out" strategy and to expand the scale of commercial presence.

\subsection{To Pay Attention to Rational Coordination of Enlarging Opening Up and Moderate Protection}

Although the further opening of domestic services market has many benefits, China is still a developing country. In the process of opening service industry especially modern service industry, if we didn't grasp the appropriate scale of opening up, it will impacts on the overall development of the national economy. Therefore, on the premise of relax supervision of service market gradually, China should open the services products market first, then gradually open service factors market and retain some appropriate protective measures.

\subsection{To Improve Legal System and Management System of Service Trade}

Firstly, Chinese government should be based on the provisions of the "General Agreement on Trade in Services", revise and improve established laws and regulations related to service industry, make new laws and regulations in the field of trade service. Secondly, we must further improve management system of the development of trade services; promote to establish management system and working mechanism by making services departments the core and different departments cooperate closely.

\subsection{To Enhance Service Trade Personnel Training}

The government should pay more attention to develop and train service trade personnel. On the one hand, the government needs to speed up the training of all kinds of personnel familiar with service trade, and reserve long-term service personnel; On the other hand, the government needs to strengthen the short-term training of existing staff and make them familiar with international service trade rules as soon as possible, in order to improve China's competitiveness in the international service trade. Making full use of finance, taxation, credit, and increasing investment in the relevant education and training a complex personnel who are familiar with international trade in services.

\section{Conclusion}

This paper aimed at analyzing China how to deal with the opportunity and challenge which the development of the world service trade has brought in the new Era, and draw the following conclusions:

First of all, the development of the world service trade show the following trends: trade in services to accelerate the development trend of service trade structure optimization, trend of service trade, unbalanced development trend, trade protection strengthening trend, business model innovation replication trend, and so on.

Secondly, the service industry of China is lagging behind, imperfect laws and regulations, incomplete management system, low personnel quality factors. The overall level of development of China's service is low and lacking of 
international competitiveness.

Finally, according to the development of the world service trade may be the impact on China, China should be a solid industrial base, optimize industrial structure, improve relevant laws and regulations of management system and other measures for the further development of Chinese service trade.

\section{References}

Chen, Jiyong, \& Yu, Daoxian. (2009). The New Trends of the Development of International Trade in Services and the Strategy of China in the Times of Knowledge Economy. World Economy Study, (4), 3-8.

China IRR. (2012). Prospects for the development trend of international service trade, [Online] Available: http://www.chinairr.org/view/V14/201205/23-99805.html (May 23 $3^{\text {th }}, 2012$ )

The State Council. (2007). Several Opinions of the State Council on accelerating the development of service industries [Online] Available: http://www.gov.cn/zwgk/2007-03/27/content_562870.htm (Mar. 27², 2007)

$\mathrm{Wu}$, hansong. (2008). International service trade development trend and China's countermeasure. Special Zone Economy, (8), 214-215.

Wu, Rong. (2008). Research on the Pattern of Division of Labor of International ServiceTrade Based on the Service Industry Transfer. East China Normal University. 